\title{
KATSAUKSIA
}

\section{Monitieteinen tutkimushanke nykysuomalaisten kielellisistä elämäkerroista}

Kesäkuussa 2017 Helsingin yliopistossa käynnistyi Koneen Säätiön rahoittama tutkimushanke Sata suomalaista kielellistä elämäkertaa (joht. Hanna Lappalainen ja Pirkko Nuolijärvi). Hankkeen taustalla vaikuttaa monitieteinen työryhmä, jossa on mukana paitsi kielitieteilijöitä myös kulttuurintutkijoita ja yhteiskuntatieteilijöitä sekä taiteilijoita (ks. Sata suomalaista kielellistä elämäkertaa -hankkeen verkkosivu). Taustalla on Heikki Paunosen (2009, 566-567) ideoima suomalaisten kielenkäyttäjäkuvien kokoelma, joka antaisi kuvan nykypäivän Suomesta monikielisenä yhteisönä. Käsillä olevaan hankkeeseen kuuluu ainoastaan kertaluontoisia haastatteluja, ei kielenkäyttötilanteiden seuraamista yksilön arjessa, kuten Paunonen katsauksessaan luonnosteli. Tällainen tilanteisen vaihtelun ulottuvuus olisi toki syventänyt kuvaa entisestään, mutta jo nykymuodossaan aineisto avaa tutkimusnäköaloja moneen suuntaan.

Hanke tuo esille nyky-Suomen kielellistä kirjoa ja lähihistoriaa. Se on uraauurtava siinä mielessä, että ensimmäisen kerran Suomessa on kerätty ja analysoitu erikielisten aineistoa samassa hankkeessa: haastateltavia ei ole rajattu äidinkieleltään suomenkielisiin vaan lisäksi haastatellaan niin perinteisten kuin uudempienkin vähemmistökielten edustajia - siis esimerkiksi ruotsin, romanin ja eri saamen kielten käyttäjiä mutta myös muiden muassa arabian, kurdin, somalin ja vietnamin puhujia.

Hankkeen ensimmäinen vaihe eli aineiston keruu käynnistettiin satavuotisen Suomen juhlavuonna syksyllä 2017. Suurin osa aineistosta kerättiin opiskelijavoimin tutkimusta ja opetusta yhdistävällä projektikurssilla. Kerromme aineiston keruun toteutuksesta tarkemmin jäljempänä. Tavoitteena oli tallentaa vähintään sata haastattelua ihmisiltä, jotka edustavat monipuolisesti vuonna 2017 Suomessa asuneita niin äidinkielen, asuinpaikan, iän kuin muidenkin sosioekonomisten muuttujien suhteen. Tilastollista edustavuutta ei kuitenkaan tavoiteltu vaan haluttiin nostaa monimuotoisuutta esiin korostamalla vähemmistökielten osuutta.

Haastatteluissa ihmisiltä on kysytty heidän osaamistaan kielistä ja kielimuodoista, niiden opiskelusta ja käytöstä arjessa. Lisäksi on kartoitettu, millaisia käsityksiä haastateltavilla on esimerkiksi omasta äidinkielestään, suomen murteista, slangista, ei-äidinkielisten käyttämästä suomesta, kirjakielen normeista sekä mediassa tai internetissä käytettävästä kielestä. Tavoitteena on luoda läpileikkaus monikielisestä ja -kulttuurisesta Suomesta ja tehdä näkyväksi, että Suomi ei ole niin homogeeninen kuin usein on ajateltu eikä se ole ollut sellainen aiemminkaan. 


\section{Mikä on kielellinen elämäkerta?}

Kielielämäkertojen keskiössä on kielenkäyttäjä: kieleen liittyvien kokemusten käsittely elämäkerran kautta nostaa esiin kielenkäyttäjän henkilökohtaisen suhteen kieliin ja hänen oman näkökulmansa niihin (Pietikäinen ym. 2011, 70). Subjektiivisen korostuksen ohella on huomattava, että niin kirjoitetut kuin suulliset kertomukset ovat yhteisesti rakennettuja (Busch 2006, 14; Pavlenko 2007, 180); oma näkökulma rakentuu dialogissa muiden kanssa, esimerkiksi haastatteluvuorovaikutuksessa (Pietikäinen-Dufva-Mäntylä 2010, 20; Pietikäinen ym. 2011, 72).

Kielellisen elämäkerran käsitettä on aiemmin käytetty yksilötason tapaustutkimuksissa (esim. Pietikäinen ym. 2011; Zentz 2015; Mononen-Straszer 2017) sekä tarkasti rajattuun vähemmistö- tai monikieliseen ryhmään kohdistuvissa tutkimuksissa (esim. Lindgren 2000; Kliuchnikova 2016). Esimerkiksi Straszer (2014) tarkastelee suomenunkarilaisia ja Pohjoinen monikielisyys -tutkimushanke (ks. Pietikäinen ym. 2011; Lilja 2012) saamelaisia, saamelaisalueella asuvia sekä meänkielisiä. Kahden maahanmuuttajataustaisen eläkeikäisen ihmisen kielivalintoja ja identiteettiä käsittelevässä artikkelissaan Mononen ja Straszer (2017) käyttävät kielielämäkertahaastattelua aineistona sen tarkastelussa, millaisia merkityksiä tutkittavat antavat elämänsä eri vaiheissa tekemilleen kielivalinnoille erityisesti identiteetin näkökulmasta ja millainen suhde heillä on osaamiinsa kieliin. Lindgren $(2000,161-162)$ on koonnut tutkimuksensa työvälineeksi haastattelemiensa henkilöiden kielellisen elämäkerran. Sen hän on laatinut niiden kysymysten pohjalta, jotka käsittelivät saamen ja suomen käyttöä, saamen taitoa ja kontakteja saamelaisiin. Myös kielenoppijoiden kokemuksia on kerätty kielielämäkerran kautta (ks. Pavlenko 2007). Kielielämäkerran painotukset vaihtelevatkin tutkimuksen tavoitteiden mukaan.

Yleisellä tasolla lingvistisesti suuntautunut elämäkertatutkimus kartoittaa yksilön kielenkäyttöä ja kielellistä repertoaaria. Nykyhetken vuorovaikutuksen lisäksi läsnä on puhujan tausta ja historialliset tekijät (Bahtin 1981, 293; Busch 2017, 355). Puhujan menneisyyden läsnäolo vuorovaikutustilanteessa korostuu kielielämäkerrallisessa tutkimuksessa, jossa tutkittavaa pyydetään eksplisiittisesti muistelemaan omaa historiaansa. Yksilön repertoaarin voi nähdä "indeksisenä elämäkertana” (Backus-Blommaert 2011, 22), mutta haastattelussa siitä tavoitetaan vain osittainen kuva. Tässä hankkeessa ei ole edes tavoiteltu sitä, että puhuja käyttäisi laajasti eri resurssejaan haastattelutilanteessa. Aiemmissa tutkimuksissa kielellistä elämäkertaa on kartoitettu haastattelujen ohella kirjallisista tuotoksista (Pavlenko 2007; Verschik 2012) ja eri keinoja yhdistellen - esimerkiksi niin, että väritystehtävän jälkeen tutkittavalta on kyselty hänen tuotoksestaan (Busch 2010; Krumm 2013; visuaalisista narratiiveista ks. Alanen ym. 2013).

Tässä hankkeessa kielelliset elämäkerrat on kerätty kertaluontoisilla teemahaastatteluilla, joita varten työryhmä laati eri näkökulmia kartoittavan ja joustavan haastattelurungon. Runko sisältää yhtäältä kaikille yhteisiä, toisaalta erilaisille haastateltaville räätälöityjä kysymyksiä, joilla kerätään tietoa tutkittavien arkipäivän kielenkäytöstä ja kieleen liittyvistä kokemuksista, kielten ja kielimuotojen muutoksista elämän aikana sekä asenteista omaa ja muiden kieltä kohtaan. Haastatteluissa käsitellään muun muassa seuraavia teemoja:

- muuttohistoria Suomessa tai muualla

- perhe, äidinkieli ja kotikieli

- ajatukset erilaisista kielimuodoista (kaupunkipuhekielet, murteet, slangi, ammattikielet)

- kokemukset kouluajan kieliympäristöstä ja kielten opetuksesta 
- kielitaito ja opittujen kielten käyttö eri tilanteissa

- työpaikan kieli ja työelämän kielitaitovaatimukset

- sosiaalisen median käyttö ja sen kielet ja kielimuodot

- kokemukset puhetapojen muutoksista

- tietoisuus omasta ja toisten kielestä

- suhtautuminen kirjoitettuun ja puhuttuun yleiskieleen sekä muiden kielimuotoihin.

Samantapaisia kysymyksiä on käsitelty myös esimerkiksi muuttajien kieltä tarkastelevissa tutkimuksissa (Ivars 1986; Nuolijärvi 1986), kieliasenteita ja -käsityksiä kartoitettaessa (esim. Vaattovaara 2009; Mielikäinen-Palander 2014) sekä vähemmistökieliä ja kielenvaihtoa koskevissa tutkimuksissa (esim. Tandefelt 1988; Lindgren 2000).

Aineisto kuvaa hyvin sitä, miten monikielisyys ja -kulttuurisuus eivät ole vain nykypäivän ilmiöitä. Esimerkkinä voidaan mainita vaikkapa aineiston vanhin haastateltava, vuonna 1913 syntynyt juutalaismies, jonka vanhemmat olivat kotoisin Puolasta ja Valko-Venäjältä ja puhuivat keskenään jiddishiä. Miehen lapsuudenperheessä Viipurissa käytettiin jiddishin ohella myös suomea ja venäjää; hänen helsinkiläinen vaimonsa taas puhui äidinkielenään ruotsia, mutta perheen kotikieleksi tuli suomi. Jiddishiä käytettiin lähinnä vanhempien välisenä salakielenä. Lapset oppivat ymmärtämään sitä, mutta lapsenlapsille kieli ei enää välittynyt.

Kielielämäkertatutkimukset ovat keskittyneet monikielisiin yksilöihin, mutta tässä hankkeessa on mukana paljon perinteisesti yksikielisiksi luokiteltuja. Kysymykset vaihtelevat hieman sen mukaan, onko puhujalla esimerkiksi maahanmuuttajatausta, mutta toisaalta samanlaisia kysymyksiä kielivalinnoista, hieman eri lailla muotoillen, voidaan esittää kaikille. Painopiste vaihtuu siis eri kielten käytöstä suomen kielen murteisiin tai kaupunkipuhekieliin sekä haastateltavan havaintoihin erilaisista kielimuodoista ja kielenkäyttötilanteista. Esimerkiksi vuonna 1929 syntynyt kansakoulun ja käsityöopiston käynyt mikkeliläisnainen kertoo, että lapsena hänen paras kouluarvosanansa oli aina äidinkielessä ja siksi hän edelleen ärsyyntyy "kielivirheistä'. Murretta hän kertoo puhuvansa tavallisesti tuttavien kanssa, mutta puhelimeen vastatessaan hän sanoo pyrkivänsä kirjakieleen. Nuoriso taas puhuu hänen mukaansa "millon mitäkii" mutta ei ainakaan Savon murretta. Kansainvälisyys nousee esiin silti tässäkin haastattelussa: naisen lapset ja lapsenlapset ovat asuneet paitsi eri puolilla Suomea myös Amerikassa, Kiinassa ja Japanissa.

Aineistoon on haastateltu myös lapsia ja nuoria, joiden elämäkerta ei luonnollisesti vielä ole yhtä monipolvinen kuin vanhempien ihmisten. Lasten haastatteluissa käsitelläänkin enimmäkseen lasten arkea, erilaisia kielenkäyttötilanteita ja haastateltavien ajatuksia kielestä. Esimerkiksi vuonna 2008 syntynyt espoolaistyttö kertoo, millaisissa tilanteissa ja keiden kanssa hän käyttää suomea ja viroa sekä mitä muita kieliä hän kohtaa arjessaan. Samanikäinen enontekiöläistyttö puolestaan kuvaa muun muassa leikkiä, jossa esitetään ulkomaalaista tai toispaikkakuntalaista puhumalla englantia tai vierasta murretta. Lasten kielenkäyttöä on käsitelty aiemmin esimerkiksi saamelaispojan monikielistä arkea tarkastelevassa tutkimuksessa, jossa on esillä monia samantapaisia kysymyksiä (Pietikäinen ym. 2008).

Kielielämäkertahaastatteluja voidaan pitää eräänlaisena välitasona yksittäistapauksia tarkastelevan mikrotason ja laajempia yhteiskunnallisia ilmiöitä kartoittavan makrotason välillä (Busch 2006, 9). Yksittäinen haastattelu on mikrotason tapaustutkimus, mutta se heijastelee yleisempiä kieleen liittyviä käytänteitä ja sosiaalisia konventioita. Kun kielellisiä elämäkertoja 
kerätään yhtenevien raamien sisällä riittävän monia, kuten tässä hankkeessa vähintään sata, vertailemalla nousee esiin makrotason ilmiöitä. Isommassa aineistossa suurempien linjojen hahmottaminen on siis mahdollista. Näin voidaan löytää tendenssejä esimerkiksi suhtautumisessa useampiin äidinkieliin tai murteisiin tai huomata käsityksiä, jotka ovat yhteisiä erilaisille vähemmistöryhmille tai vaikkapa maahanmuuttajille ja maan sisällä muuttaneille. Esiin voi nousta myös sellaisia ikäkausisidonnaisia ilmiöitä, jotka yhdistävät eri kielitaustoista tulevia mutta samanikäisiä ihmisiä. Toisaalta voidaan tarkastella myös sitä, kuinka paljon samanlainen kulttuurinen ympäristö nostaa esiin samantapaisia tarinoita (vrt. Verschik 2012).

Narratiivisuus on olennainen osa kielielämäkertoja; ihminen jäsentää elämäänsä kertomusten kautta, ja kielielämäkertaa kartoittava haastattelu sisältää pieniä kertomuksia erilaisista kielellisistä ja muista kokemuksista elämän varrelta (Busch 2006, 14). Tähän myös tietyin haastattelukysymyksin on kannustettu (esim. Milloin ensi kertaa kiinnitit huomiota siihen, että ihmisillä on erilaisia puhetapoja? Missä tilanteessa?). Soveltavassa kielentutkimuksessa narratiivit, etenkin kirjalliset narratiivit, ovat olleet jo pitkään suosittu tapa kerätä aineistoa (ks. Pavlenko 2007; Alanen ym. 2013). Myös visuaalisuus on noussut vahvasti esiin, ja esimerkiksi kielenoppijoiden kokemuksia on kerätty visuaalisten narratiivien avulla (Kalaja ym. 2008).

Kielellisten elämäkertojen kokonaistarkastelun lisäksi vertailukelpoisten haastattelujen kokoelma mahdollistaa fokusoinnin tarkempiin yksittäisiin kysymyksiin. Suurin osa aineistoon perustuvista tutkimuksista todennäköisesti käsitteleekin jotakin tiettyä teemaa kartoittavaa kysymyskokonaisuutta; hankkeen ensimmäinen pro gradu -tutkielma tarkastelee äidinkielisten suomenpuhujien työelämän kielenkäyttöä ja siihen liittyviä kysymyksiä (Asikainen 2018). Aineistosta voi tarkastella myös vertaillen esimerkiksi eri-ikäisten käyttämiä äänne- ja muotopiirteitä. Taustamuuttujat voi näissäkin tapauksissa ottaa monipuolisesti huomioon, koska jokaisesta haastatellusta on paljon sosiaalisiin verkostoihin, harrastuksiin ja kielellisiin kokemuksiin liittyviä tietoja niin taustalomakkeella kuin haastattelussakin. Erityisesti haastattelujen sisältöön keskittyvissä tutkimuksissa on olennaista ottaa huomioon myös se, missä tilanteessa näkemykset on tuotettu ja miten (Pavlenko 2007). Videomateriaali antaa mahdollisuuden tarkastella kielellisen elämäkerran rakentumista haastatteluvuorovaikutuksessa haastattelijan ja haastatellun yhteisenä toimintana, kun rakentumisprosessi voidaan osoittaa hienojakoisen analyysin kautta, ei ainoastaan yleisellä tasolla todeten (De Fina-Georgakopoulou 2012, 81; ks. myös Lilja 2012). Haastattelun tai siinä esiintyvien yksittäisten näkökulmien ideologista taustaa ja oletuksia on puolestaan mahdollista analysoida esimerkiksi tutkimuskäyttöön saatujen oppimispäiväkirjojen kautta. Näitä päiväkirjoja syntyi projektikurssilla, josta kerromme seuraavaksi aineistonkeruun esittelyn yhteydessä.

\section{Aineistonkeruu opiskelijavoimin}

Pääosa aineistosta kerättiin yhteistyössä opiskelijoiden ja toisten yliopistojen kanssa. Kurssi "Kielellinen elämäkerta talteen" järjestettiin syksyllä 2017 Helsingin, Itä-Suomen, Oulun ja Tampereen yliopistoissa ja keväällä 2018 Turun yliopistossa. Kurssilla opiskelijat koulutettiin tutkimushaastattelun tekoon sekä ELAN-ohjelman käyttöön ja karkeaan litterointiin. Haastattelujen ja litteroinnin ohjeet sekä kurssilla käytettävät materiaalit toimitettiin Helsingistä, mutta opetuksesta vastasivat pääosin yhteistyöyliopistojen omat opettajat. Kurssin suoritti loppuun yhteensä 77 kieli- ja kulttuuriaineiden opiskelijaa, joista jokainen teki ja litteroi vähintään yhden 
haastattelun. Kurssitöinä saatiin kerätyksi peräti 88 haastattelua. Kurssien koordinoinnista vastasi hankkeen post doc -tutkija Katri Priiki.

Haastateltavien valinnassa otettiin huomioon väestöpainotettu edustavuus, ja tavoitteena oli, että haastateltavat edustavat nyky-Suomessa asuvia ihmisiä ja heidän kieliään ja kielimuotojaan suhteessa ikään, sukupuoleen, asuin- ja syntymäpaikkaan sekä ammattiin ja koulutukseen. Haastateltavien valikoinnin tueksi laadittiin tavoitematriisi, jonka mukaan aineistoa keräävät opiskelijat ehdottivat haastateltavaksi suomen eri murteita ja kaupunkipuhekieliä sekä eri vähemmistökieliä puhuvia ihmisiä Suomen suurimmista kaupungeista sekä maakuntien pienemmiltä paikkakunnilta.

Matriisissa tavoitteeksi asetettiin haastatella eri-ikäisiä ihmisiä, miehiä ja naisia, sekä valita vähemmistöryhmistä tyypillisiä edustajia. Tarkkaan tilastolliseen edustavuuteen ei kuitenkaan pyritty, sillä sadan ihmisen otokseen ei silloin mahtuisi kovinkaan monen vähemmistöryhmän edustajaa. Moninaisuuden korostamiseksi vähemmistökielten puhujien osuutta sadan ihmisen otoksessa kasvatettiin siis tarkoituksella. Ruotsin kieli sai tutkimusaineistossa erityisaseman siten, että ruotsinkielisten haastattelut tehtiin pääsääntöisesti ruotsiksi ja viittomakielten käyttäjien viittomakielellä. Muiden vähemmistöjen edustajien haastattelun kieli on suomi ja haastattelijat valtaväestön edustajia.

Haastattelujen kielivalintaa pohdittiin hankkeen monitieteisessä työryhmässä pitkään. Epäilemättä haastateltavien kannalta olisi luontevinta puhua kieliasioista itselleen vahvimmalla kielellä tai käyttäen kahta kieltä; toisaalta oli tiedossa, että joidenkin kielten osalta olisi vaikea löytää sopivaa haastattelijaa. Lisäksi analyysi olisi tällöin perustunut käännökseen, ja resursseja olisi tarvittu selvästi enemmän kuin nykyratkaisulla. Niinpä päädyttiin siihen, että haastattelujen kieli on suomi tai ruotsi (poikkeuksena kuitenkin viittomakielet), jolloin tutkimusaineisto tarjoaa materiaalia myös sen tutkimiseen, millaista on erilaisista kielitaustoista tulevien suomi. Tämä oli luontevaa, koska hankkeen työryhmässä on nimenomaan suomen ja ruotsin kielen tutkijoita. Haastattelujen analyysissa on kuitenkin kiinnitettävä erityistä huomiota siihen, että haastateltava ei välttämättä ole kyennyt ilmaisemaan kaikkea, mitä hän vahvemmalla kielellään olisi voinut kertoa, ja tämä on myös näiden haastatteluaineistojen heikkous (Pavlenko 2007, 172).

Tässä vaiheessa voi jo arvioida kriittisesti joukkoistamalla toteutetun aineistonkeruun hyviä ja huonoja puolia. Joukkoistaminen säästi huomattavasti taloudellisia resursseja, sillä jos kaikki haastattelut olisi toteutettu ja litteroitu palkattujen tutkijoiden tai tutkimusavustajien voimin, hankkeen budjetti olisi ollut moninkertainen ja tuskin rahoittajaakaan olisi löytynyt. Samaan aikaan toteutetut kurssit eri yliopistoissa ovat myös olleet ajankäytöllisesti onnistunut ratkaisu, sillä suurin osa aineistosta saatiin kokoon varsin lyhyessä ajassa. Ei voi myöskään väheksyä opiskelijoiden kokemuksia kurssista. Kurssipalautteessa moni kiitteli mahdollisuutta osallistua oikeaan tutkimushankkeeseen, jossa sai omakohtaisesti nähdä prosessin kulun, vaikuttaa siihen ja kokea olevansa osa kokonaisuutta, josta syntyy jotain suurempaa. Kurssi harjoitti osaltaan myös monia yleisesti työelämässä tarvittavia taitoja, kuten aikatauluttamista ja haastattelun tekemistä. On toki selvää, että opastuksesta ja mahdollisimman tarkoista ohjeista huolimatta haastattelujen toteutuksessa on runsaasti variaatiota - enemmän kuin olisi silloin, jos aineiston keräisi muutama kouliintunut haastattelija. Joissakin haastatteluissa näkyy myös selvästi haastattelijan jännittyneisyys ja kokemattomuus. Kaikkineen opiskelijat suoriutuivat tehtävästä kuitenkin yllättävän hyvin, ja kaikki haastattelut soveltuvat tutkittaviksi jostain näkökulmasta. Opiskelijoiden kautta löytyi myös kiinnostavia haastateltavia; pelkästään tutkijoiden 
omia verkostoja käyttäen kuva olisi muodostunut paljon kapeammaksi. Kun toimijoita on ollut monessa eri yliopistossa, kokonaisuuden koordinointi on ollut vaativa urakka, mutta yhteistyö eri yliopistojen kanssa on sujunut erinomaisesti.

\section{Mitä tästä eteenpäin?}

Hanketta ja ensimmäisiä aineistosta tehtyjä havaintoja esiteltiin kevään 2018 Kielitieteen päivillä, ja niistä on kerrottu myös kansainvälisissä konferensseissa. Ensimmäiset opinnäytetyöt ovat valmistuneet (esim. Asikainen 2018), ja uusia on tekeillä. Keruun valmistuttua aineisto avataan tutkimuskäyttöön Kielipankin ja Svenska litteratursällskapetin kautta. Hankkeen tutkijoilla on suunnitteilla sosiolingvististä, narratologista, kansatieteellistä, folkloristista ja sosiaalitieteellistä tutkimusta. Lisäksi aineistosta voi löytyä tutkittavaa myös esimerkiksi historian ja sosiaalipsykologian sekä kaupunki- ja nuorisotutkimuksen piirissä.

Työryhmässä on mukana valokuvaaja, joka ottaa muotokuvan osasta haastatelluista, joten tiede yhdistyy uudella tavalla taiteeseen. Kuvista ja kerätyistä kielielämäkerroista teksti- ja ääninäyttein koostetaan näyttely, joka on esillä tammi-helmikuussa 2019 Helsingissä. Tämän jälkeen näyttely kiertää ainakin Tampereella, Oulussa ja Joensuussa. Suurin osa tutkittavista on siis ollut valmis antamaan oikeat kasvot kielielämäkerroille ja esiintymään myös omalla etunimellään.

Hanke nojaa vahvasti aiempaan tutkimukseen mutta toisaalta tarjoaa harvinaisen laajan kieliaineiston, joka mahdollistaa uudenlaisen vertailun ja joka toivottavasti herättää kiinnostusta myös kielentutkimuksen ulkopuolella. Tärkeä osa projektia onkin saattaa tutkimushankkeen myötä kertyvää tietoa myös suuren yleisön tietoisuuteen.

\section{Katri Pritki, KaArina Mononen ja Hanna Lappalainen}

Katri Priiki

katri.priiki@helsinki.fi
Kaarina Mononen kaarina.mononen@helsinki.fi
Hanna Lappalainen hanna.lappalainen@helsinki.fi

Suomalais-ugrilainen ja pohjoismainen osasto Humanistinen tiedekunta PL 24 00014 Helsingin yliopisto

\section{Lähteet}

Alanen, Ritkka - Kalaja, Paula - Dufva, Hannele 2013: Visuaaliset narratiivit ja valmistuvien aineenopettajien käsitykset vieraiden kielten opettamisesta. Tirna KeISAnen, Elise KärKKÄInen, Mirka Rauniomaa, Pauliina Siitonen ja Maarit Siromaa (toim.): AFinLA-e Soveltavan kielitieteen tutkimuksia 5, 41-56. Saatavilla https://journal.fi/afinla/article/view/8738.

AsiKainen, ANNIINa 2018: "Et kyl mä nyt uskosin et mun puheesta niinku tolkun saa ja sehän nyt pitäs riittää"-kieli ja kieliasenteet työelämässä. Suomen kielen pro gradu -tutkielma. Helsinki yliopisto.

Bahtin, Mikhail 1981: The dialogic imagination: four essays by M.M. Bakhtin. University of Texas Press, Austin.

BUSCH, BRIGITTA 2006: Language biographies - approaches to multilingualism in education and linguistic research. Language biographies for multilingual learning. PRAESA - Occasional Papers 24, 
5-18. Saatavilla http://www.paulroos.co.za/wp-content/blogs.dir/22/files/2012/07/Paper24.pdf 2010: Die Macht präbabylonischer Phantasien. Ressourcenorientiertes sprachbiographisches Arbeiten. Zeitschrift für Literaturwissenschaft und Linguistik 40, 58-82. https://doi.org/10.1007/ BFo3379844

2017: Expanding the notion of the linguistic repertoire: on the concept of Spracherleben-The lived experience of language. Applied Linguistics 38/3, 340-358. https://doi.org/10.1093/applin/ amvo3o

Ivars, ANN-MARIE 1986: Från Österbotten till Sörmland. En undersökning av emigration och språklig anpassning. Studier i nordisk filologi 66. Svenska litteratursällskapet i Finland, Helsingfors.

Kalaja, Paula - Alanen, Riikka - Dufva, Hannele 2008: Self portraits of language learners. Finnish students draw and tell. Paula Kalaja, Vera Menzer ja Ana Maria Barcelos (toim.): Narratives of learning and teaching in EFL. Palgrave Macmillan, London.

Kliuchnikova, Polina 2016: Linguistic biographies \& communities of language of Russian speakers in Great Britain. Doctoral thesis, Durham University. Saatavilla http://etheses.dur.ac.uk/11374/.

Krumm, Hans-Jürgen 2013: Multilingualism and Identity: What Linguistic Biographies of Migrants Can Tell Us. Peter Siemund, Ingrid Gogolin, Monika Edith Schulz ja Julia Davydova (toim.): Multilingualism and language diversity in urban areas: acquisition, identities, space, education, 165-176. Hamburg studies on linguistic diversity 1.

LILJA, NIINA 2012: Kieli saamelaisuutta määrittämässä. Saamelaissyntyisten henkilöiden haastattelupuheessa rakentuvat saamelaisuuden kategoriat. Puhe ja kieli 32 (3), 127-150. Saatavilla https:// journal.fi/pk/article/view/7619.

LINDGREN, ANNA-RIITTA 2000: Helsingin saamelaiset ja oma kieli. SKS, Helsinki.

Mielikäinen, Aila - Palander, MarJatta 2014: Miten suomalaiset puhuvat murteista? Kansanlingvistinen tutkimus metakielestä. SKS, Helsinki.

Mononen, KAARINA - STRASZER, BogLÁRKa 2017: Monikieliset ikääntyvät ihmiset ja monimuotoiset kielten repertuaarit: miten kielivalintoja ja suhdetta kieliin kuvataan kielellistä elämäkertaa valaisevassa haastattelussa? Sirkku LatomaA, Ninna Lilja ja Emilia LuUkкa (toim.): Kielitietoisuus eriarvoistuvassa yhteiskunnassa - Language awareness in an increasingly unequal society. AFinLAn vuosikirja 2017, 133-160. Suomen soveltavan kielitieteen yhdistyksen julkaisuja 75, Jyväskylä. Saatavilla https://journal.fi/afinlavk/article/view/60741.

NuoliJärvi, Pirkko 1986: Kieliyhteisön vaihto ja muuttajan identiteetti. Tietolipas 10o. SKS, Helsinki.

Paunonen, HeIkKi 2009: Suomalaisen sosiolingvistiikan ja kielisosiologian näkymiä. Virittäjä 113 (4), 557-570.

Pavlenko, Aneta 2007: Autobiographic narratives as data in applied linguistics. Applied Linguistics 28(2), 163-188. https://doi.org/10.1093/applin/ammoo8

Pietikäinen, Sari - Alanen, Riıkka - Dufva, Hannele - Kalaja, Paula - Leppänen, Sirpa - PitkäNEN-Huhta, ANNE 2008: Languaging in Ultima Thule: Multilingualism in the life of a Sami boy. International journal of multilingualism 5, 79-99. https://doi.org/10.1080/14790710802152289

Pietikäinen, Sari - Dufva, Hannele - Mäntylä, Katja 2010: Monikielisyys liikkeessä: monikielisen perheen kielelliset resurssit. Mikel Garant ja Mirja Kinnunen (toim.): AFinLA-e: Soveltavan kielitieteen tutkimuksia 2, 17-30. Saatavilla https://journal.fi/afinla/article/view/3873.

Pietikäinen, Sari - Lainiala-Kankainen, Sirkka - Huss, Leena - Salo, Hanni 2011: Kieli ja kokemus. Vähemmistökieli kolmen perhesukupolven kielielämäkerroissa. Puhe ja kieli 31 (2), 67-88. Saatavilla https://journal.fi/pk/article/view/4663/4380.

Mäntylä, Katja - PietikäInen, Sari - Dufva, Hannele 2009: Kieliä kellon ympäri: Perhe monikielisyyden tutkimuksen kohteena. Puhe ja kieli 29 (1), 27-37. Saatavilla https://journal.fi/pk/article/ view/4791/4489.

Sata suomalaista kielellistä elämäkertaa -hankkeen verkkosivut. https://blogs.helsinki.fi/1oosuomalaista/ SKS = Suomalaisen Kirjallisuuden Seura

STRASZER, BOGLÁRKA 2014: Maahanmuuttajien kielitaito - yhteiskunnan resurssi vai yksilön kätköissä oleva pääoma? Esimerkkinä toisen polven suomenunkarilaiset. MaARit Mutta, Ilmari Ivaska ja Paulinna Peltonen (toim.): Tulevaisuuden kielenkäyttäjä. Language users tomorrow. 
AFinLAn vuosikirja 2014, 109-131. Suomen soveltavan kielitieteen yhdistyksen julkaisuja 72. Jyväskylä. Saatavilla https://journal.fi/afinlavk/article/view/60056.

TANDEFelt, MARIKa 1988: Mellan två språk. En fallstudie om språkbevarande och språkbyte i Finland. Acta Universitatis Upsaliensis. Studia Multiethnica Upsaliensia 3. Uppsala universitet, Uppsala.

VAattovaARA, Johanna 2009: Meän tapa puhua. Tornionlaakso pellolaisnuorten subjektiivisena paikkana ja murrealueena. SKS, Helsinki.

VERSCHIK, ANNA 2012: Keeleliste elulugude uurimisvõimalusi: Dagmar Normeti mitmekeelne lapsepõlv Eestis. Possibilities of research on linguistic biographies: Dagmar Normet, a multilingual childhood in Estonia. Methis: Studia Humaniora Estonica. Vol 4 No 5-6: Special issue on life writing "The Role of Life Writing in Estonian Cultural History", 176-188. https://doi.org/10.7592/methis. v4i5-6.527

ZENTZ, LAUREN 2015: 'Is English also the place where I belong?': linguistic biographies and expanding communicative repertoires in Central Java. International Journal of Multilingualism 12 (1), 6892. https://doi.org/10.1080/14790718.2014.943233 